\title{
Analysis of Packaging and Brand Design Assistance Programs by the Ministry of Industry in Improving Product Quality
}

Restu Fahrunnisa ${ }^{1 *}$,

Dian Marlina Verawati ${ }^{2}$,

1,2 Departement of Management, Faculty of Economic, Universitas Tidar, Magelang, Indonesia

ARTICLE INFO ABSTRACT

ISSN: 2723-1097

Small and Medium Industries (SMIs) in the face of competition have obstacles that are the ability of designing the brand and good packaging. The Directorate General of IKMA provides support for industry players, especially SMIs, to improve the

Keywords: quality of their product packaging through the Brand Design and Packaging Assistance Program for small and medium industries. The purpose of this study is

Small and medium industries, Brand design, Packaging design, product quality to describe how the program can run in Magelang City, with the limitation of the problems, that are: (1) Procedures for submitting and distributing packages and Brand Design assistance programs as a form of implementing program distribution; and (2) Sustainability after channeling the program in achieving its objectives, specifically improving product quality. The results of this study are from the 24 SMIs, 88\% have used a new packaging design and 67\% have experienced market expansion. On the other hand, 13\% have not used a new design and 33\% have not yet experienced market expansion.

\section{Introduction}

Currently, almost all business sectors are affected by global competition. Global competition occurs when a region (in this case the State) competes to seize markets and opportunities (market and opportunity share). Global scale business competition encourages industries to survive with superior products that are able to compete in the global market. Meanwhile, global corporate competition (global company) arose as a result of transnational companies belonging to developed countries that began to expand to developing countries, including Indonesia. This of course makes the competition between domestic companies and global companies tighter, so that it is feared that they can seize the domestic market share. Therefore, in the face of this global competition,

Micro, small and medium enterprises (MSMEs), from a global perspective, have been recognized as having a role in economic growth and development in a country. MSMEs are recognized as very important because of their characteristics that distinguish them from large industries, especially because MSMEs are labor-intensive enterprises, found in all locations to rural areas, depend on local raw materials, and are the main providers of basic needs for low-income people. In economic development, MSMEs are one of the foremost supporters of economic development

Journal of Business and Management Review Vol. 2 No. 32021 Page 203-215

DOI: $10.47153 /$ jbmr23.992021

*Corresponding Author

Email address: restufahrunnisa@gmail.com 
(World Bank, 2005). Indonesian MSMEs have proven to be making a significant contribution against added value to the country's economiy and has provided opportunities the largest proportion of employment compared to gross domestic product (GDP) in Indonesia (Sahban, 2017). Data from the Ministry of Cooperatives and Small and Medium Enterprises (Kemenkop UKM) shows that in 2018 there were 64.2 million UMKM units from the total business units in Indonesia, namely 64.1 million (99\%), which managed to absorb a workforce of 116.9 million people from the total workforce. work in Indonesia, namely 120, 6 million people (97\%) (Susilo, 2007). MSMEs also contributed to the formation of GDP in 2018 amounting to 8,573,895 billion from a total of $14,038,598$ billion contributions from the business world in Indonesia (61.07\%).

In the global competitive climate, the contribution of MSMEs, especially in small and medium-sized industries (SMI) in the export sector, tends to be low. As much as 14.5 percent, lost to neighboring countries such as Malaysia which is over 20 percent, Vietnam is almost 20 percent, Thailand has reached 35 percent. (Santia, 2020) One of the obstacles for SMIs in facing competition is the ability to design good and attractive brands and packaging. Attractive packaging is considered to increase production costs, meaning that entrepreneurs are faced with the dilemma of reducing profits or increasing selling prices. Entrepreneurs who are aware of the important role of packaging, are faced with limited facilities and knowledge of packaging designs that are preferred by the market and in accordance with export standards.

As something that is immediately visible to consumers, packaging is a solution to attract consumer interest (Cenadi, 2000). Packaging now not only serves as a container and protector for products, but also becomes a tool in competition. The results of research conducted by Wardhani and Agustina (2015) state that product packaging variables affect competitiveness, in line with the results of research in the field that consumers want a product more if the product packaging is innovated, such as including the composition and product information on the packaging.

The Ministry of Industry (Kemenperin) through the Directorate General of Small and Medium Industries (IKMA) continues to improve the competitiveness of IKMs by improving the quality of packaging. In 2003, the Directorate General of IKMA established a Packaging and Brand Design Clinic which aims to provide support to IKM to improve the quality of their product packaging. Among them, providing guidance and consulting on packaging design and brand development in the regions, assistance in printing packaging and assistance with packaging and brand design. The clinic's function is supported by 25 regional packaging houses throughout Indonesia. Until 2020, 913 IKM have been facilitated, of which $82.04 \%$ are IKM in the food and beverage sector (Kemenperin, 2020) 
The Office of Industry and Trade (Disperindag) of Magelang City has started submitting packaging and brand design assistance since 2018 and the program is active in 2019. During the program, monitoring and evaluation has never been conducted to find out how the program is implemented and sustainable. Can it achieve its goal, namely improving product quality and can make positive changes for the sustainability of IKM in Magelang City. Based on the description above, it is the basis for the author to conduct an analysis related to the implementation of the Packaging and Brand Design Assistance Program by the Ministry of Industry in Improving Product Quality (Case Study at IKM Magelang City). With the aim of knowing: (1) Procedure for submitting and distributing packaging and mark design assistance programs as a form of implementation of program distribution; and (2) Sustainability after program distribution in achieving goals.

\section{Literature Review}

\section{Product Quality}

Product quality is the advantage of a product that is compared to competitor's products. Mundir (2012) defines quality as one of the factors that attracts interest based on considerations. If consumers get satisfaction with a product, then consumers will be interested in buying that product. The dimensions of product quality measurement according to Tjiptono 1997 (in Firmansyah, 2019), the indicators of product quality are as follows: (1) Performance, a characteristic in the form of core operating performance in a product purchased; (2) Additional features, are complementary characteristics for the product; (3) Reliability, is the product's ability to withstand as long as possible from damage or the possibility of failure to use; (4) Compliance with specifications, is how the characteristics of the product design can meet the predetermined standards; (5) Durability, related to how long the product can continue to be used; (6) Aesthetics, or attraction that can bind the five senses.

\section{Packaging Design}

According to Klimchuk and Krasovec 2006 (in Firmansyah, 2019) Packaging is a creative design that links shapes, structures, materials, colors, images, typography and design elements with product information so that products can be marketed. Basically, packaging has the main function as a protection and a place to store a product. However, several factors give packaging an additional function as a marketing vehicle. Kotler and Armstrong (2008) state that innovative packaging is able to provide benefits for companies in winning the competition and driving sales. According to Firmansyah $\underline{(2019)}$ in designing or designing a product packaging, we can pay attention to several basic aspects in determining the product packaging itself, including: (1) The attractiveness of the packaging, this is very important in order to capture the stimulus 
by consumers conveyed by the producer. The goal is to lure consumers to choose the products offered; (2) Visual attractiveness, in relation to the appearance of the face such as on the packaging or label on the product, which includes color, shape, brand / logo, illustrations, text / typography, layout.

Indicators of good packaging design refer to Wirya's (1999) statement regarding the attractiveness of packaging, namely: (1) The guarantee is able to protect the product; (2) Ease of product storage, for example, can be opened and closed again; (3) Packaging with appropriate portions; (4) The packaging is designed to be reusable; (5) Easy to carry; (6) Packaging that is easy to use, spend, and refill.

\section{Brand}

Firmansyah (2019) states that a brand is a name, symbol, sign, design or a combination of them to be used as the identity of an individual, organization or company in goods and services owned to differentiate it from other service products. A strong brand is characterized by the recognition of a brand in society, high brand association for a product, a positive perception of the market and high consumer loyalty to the brand. A brand is considered capable of describing the quality of a product to buyers, giving a brand will encourage entrepreneurs to provide a more consistent and guaranteed quality (Simamora, 2001). For consumers, brands play a role as identification of product sources, assigning responsibility to producers and distributors, reducing risk, and so on (Tjiptono, 2015)

Brand Affect Indicators According to Gecti and Zengin (2013) as follows: (1) Brand gives satisfaction, namely (a) Making many product choices (b) Making many price choices; (2) Brand makes satisfaction, namely: (a) Model according to customer desires (b) Product in accordance with the costs incurred by the customer (3) Feel satisfied when using the brand (a) Feel comfortable when using the product (b) Feel confident when put on the product

\section{Small and Medium Industry (SMI)}

Regulation of the Minister of Industry of the Republic of Indonesia Number 64 of 2016 defines industry as a series of economic activities that work to process raw materials by utilizing Industrial resources to produce goods of sale value. Industrial business activities include: (a) Small industry, (b) medium industry; and (c) large industry. Small industry is an industry that employs a maximum workforce of nineteen people, the investment value is less than 1 billion rupiah, excluding business premises such as land and buildings. 


\section{Methods}

This study used descriptive qualitative method. This method was chosen because the descriptive method has the characteristic of allowing systematic documentation of program implementation, so that it can be used as a basis for inductive theory development (Muhadjir: 1996). Techniques used in data collection include noninteractive and interactive techniques. Non-interactive techniques are analysis of existing documents, while interactive techniques are obtained through in-depth interviews and role observation (LeComte, in Nugrahani, 2014).

Researchers act as human instruments by observing directly for approximately 4 (four) weeks by participating with the Department of Industry and Trade to assist SMI players in program submissions. Data collection was carried out by in-depth interviews (indept interview) to owners and employees involved in the businesses of 33 SMI units participating in the Packaging and Brand Design Program, as well as 2 industrial assistants from the Magelang City Disperindag who have responsibility for the Packaging Design Program. and Brands. Other data were obtained from books, government regulations, records of the City of Magelang Disperindag, and other relevant sources.

The validity of qualitative research is still carried out, based on the accuracy of research results based on various perspectives, both researchers, participants and readers. In this study, the validity test used was data triangulation. Triangulation (Moleong, 2011) is to make comparisons of the data obtained, with sources or criteria other than these data, with the aim of increasing the accuracy of the data. In this study, triangulation was carried out based on the source and method: 1) Source triangulation, namely comparing the subject's words with the informants' words. Data is not only obtained from one source, but is obtained from several sources such as business owners, employees, and companion staff from the department. This means that the data obtained is more reliable. 2) Triangulation methods, namely comparing data from direct observation with data from interviews and contents of related documents.

Data Analysis Process: (1) Researchers make direct observations in the field while collecting data; (2) When the data is collected, the analysis process begins with the preparation of the researchers' reflection, which is a framework of thought, and ideas, on the data found (Bogdan \& Biklen, 1982). Through this reflection, the data stabilization process is carried out. (3) interactive process. Any data that is obtained, is compared with other data on an ongoing basis; (4) Any conclusions drawn are reinforced by a continuous data collection process. At the verification stage, it is possible to trace back all research evidence, if the data is deemed less stable for the basis for drawing conclusions.

\section{Results and Discussion}


Magelang City is one of the small cities located in Central Java Province, to be precise in the middle of Magelang Regency which is famous for its souvenirs center. With an area of only $18.5 \mathrm{~km} 2$, Magelang City has 1,692 Small and Medium Industry Units (SMI). The existence of this SMIs is able to absorb 2,594 workers. Of the total SMIs, $61.9 \%$ is in the food industry.

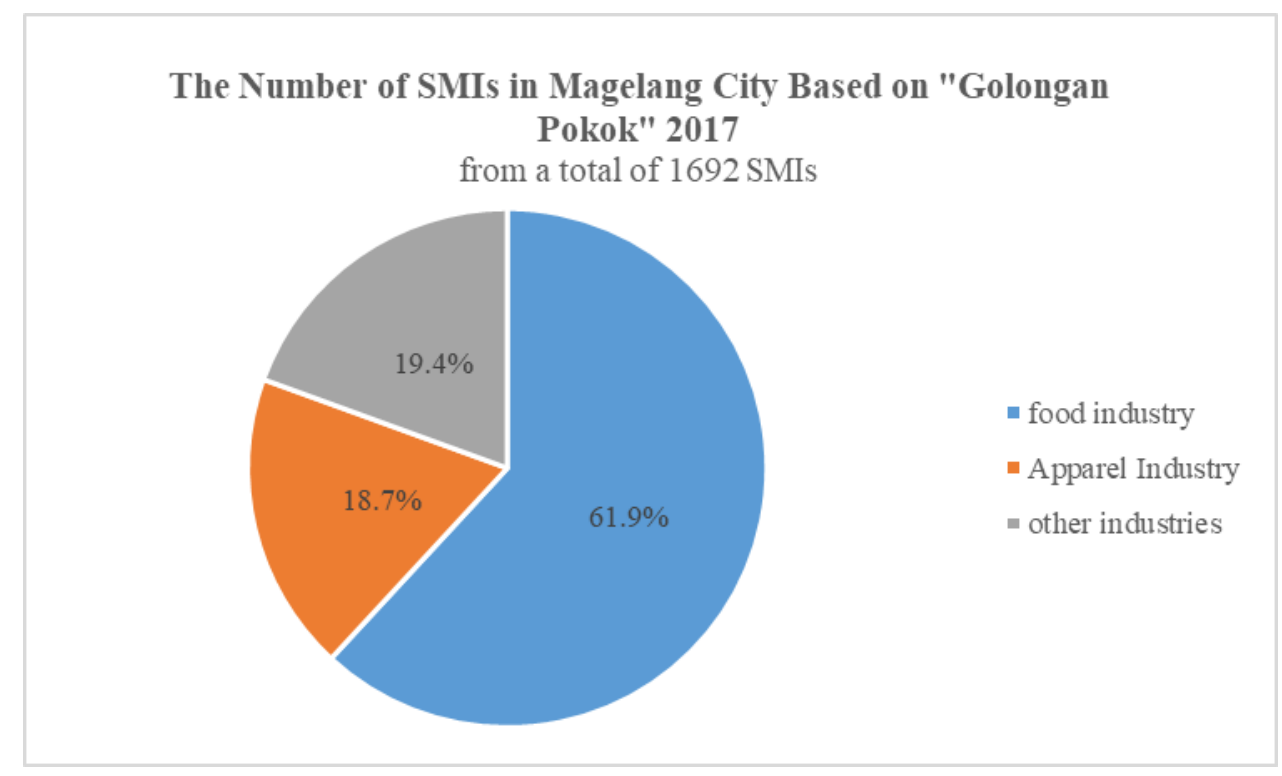

Table 1. The Number of SMIs in Magelang City Based on "Golongan Pokok" 2017

Source: Archives of the City of Magelang Disperindag 2019

Firmansyah (2019) states that currently there are so many small businesses and home industries that produce various kinds of special foods from their respective regions. Entering into trade competition, a product requires an identity. Product identity is obtained through the design of the brand and packaging that is unique and different from competitors' products and according to product needs. Unfortunately these two things become obstacles for SMIs in Magelang City. This is related to the lack of skilled human resources in design and limited knowledge regarding the importance of a good brand and packaging for a product.

The City of Magelang Disperindag sees this situation and continues to try to provide stimulus to suppress these obstacles. One of them is by organizing packaging and brand design training. However, due to limited facilities, this program is deemed ineffective. Industry players only stop at the training stage, and not many actually implement them in their businesses. Therefore, the City of Magelang Disperindag began in 2018 to assist in the process of submitting the Packaging and Brand Design Assistance Program organized by the Directorate General of IKMA through the Packaging and Brand Design Clinic. 


\section{Procedure for Submission and Distribution of Packaging and Brand Design Assistance Programs}

Program submissions can be made by SMI actors independently by visiting the Magelang City Industry and Trade Office to ask for an application form. However, during the observation period, researchers have never met SMI actors who voluntarily come to register but get recommendations from SMI assistants who periodically come to industrial locations to record the development of SMI.

When the facilitator recommends and the SMI actor agrees to join the program, the next step is that the SMI actor is required to fill out a submission form guided by the assistant and fulfill other administrative requirements. The other administrative requirements that must be met are:

For Brand Design Submissions:

(1) Photocopy of ID card

(2) The previous packaging design stickers with a size of $6 \times 6$ are 2 pieces

(3) 2 pieces of 6000 stamps

(4) IUMK (Optional)
For packaging design submissions:

(1) PIRT / proof of Halal certificate (Optional)

(2) Photocopy of ID card

(3) Old Packaging

(4) 2 pieces of 6000 stamps

After the application quota is met, the functional representatives from the industrial sector from the Industry and Trade Office will continue the application for the Packaging and Brand Design Assistance program to the Packaging and Brand Design Development Clinic in Jakarta. Apart from being armed with a submission file from SMI, processed products are also a requirement at this stage of submission. Processed products are needed as material for the feasibility of distributing aid.

Until October 2019, 33 submissions were recorded. 1 (one) of them receives assistance in the form of finished packaging. Meanwhile, the rest received assistance in the form of CDs containing softcopy of the brand design and / or print-ready packaging. The following is data on Brand and Packaging Design assistance for Magelang City SMIs facilitated by the Ministry of Industry's IPR Clinic in October 2019:

\begin{tabular}{cll}
\hline NO & \multicolumn{1}{c}{ MERK NAME } & \multicolumn{1}{c}{ PRODUCT } \\
\hline 1 & Marem & Gethuk \\
2 & Garuda & Bolu Cukil / Baked Cake \\
3 & Berkah Abadi & Chips \\
4 & Larasta & Tofu Chips \\
5 & Jaya Makmur & Vegetable Chips \\
6 & Bolle Telo & Cake
\end{tabular}




\begin{tabular}{cll}
\hline NO & \multicolumn{1}{c}{ MERK NAME } & \multicolumn{1}{c}{ PRODUCT } \\
\hline 7 & 35 & Banana Sale \\
8 & Badeng Duri Lunak Magelangan & Bandeng Duri Presto \\
9 & Gading Mas & Rempeyek \\
10 & Rumah Coklat Magelang & Various Processed Chocolate \\
11 & Anda & Bakery, Cake, Snack \\
12 & Dewa & Ginger Syrup \\
13 & Candy Bevatos & Pastel,Onde Ketawa,Pangsit \\
14 & Kondang & Gethuk \\
15 & Sari Ajeng & Shredded fish ,Nata de Aloe \\
16 & Sambel Pecel Upik & Sambal Pecel \\
17 & Cheese Stick Rakedam & Cheese Stick \\
18 & Getuk Tri Warna Lezat & Getuk Tri Warna \\
19 & Tahu Bakso Ammara & Tahu Bakso \\
20 & Chistik Sn4b & Chistik \\
21 & Bakpia Basah Echo & Wet Bakpia \\
22 & Aneka Rempeyek Salma & Various Rempeyek \\
23 & D'muprull & Toast bread \\
24 & Chiffon Cake Bu Tri & Chiffon Cake \\
25 & Tepung Aci Berbumbu Mas Miko & Seasoned Aci Flour \\
26 & Telo Goreng Wong Magelang & Fried Telo \\
27 & Brownies Jagung Magelang & Corn Brownies \\
28 & Bandeng Presto Kinanthi & Bandeng Presto \\
29 & Mekar jaya & Cheese stick \\
30 & Kafka Attaya & Bolu Jadul \\
31 & Abonz & Shredded Chicken \\
32 & Kerupuk Ikan Lethek & Processed fish \\
33 & D'imutz Choco & Chocolate Candy \\
\hline & &
\end{tabular}

the 33 submissions above, the distribution of aid was not given simultaneously but in stages. In October 2019, 24 SMIs or 73\% of the total submissions have received assistance in the form of Soft File Packaging Design as of June 2020 and the rest are still waiting. 


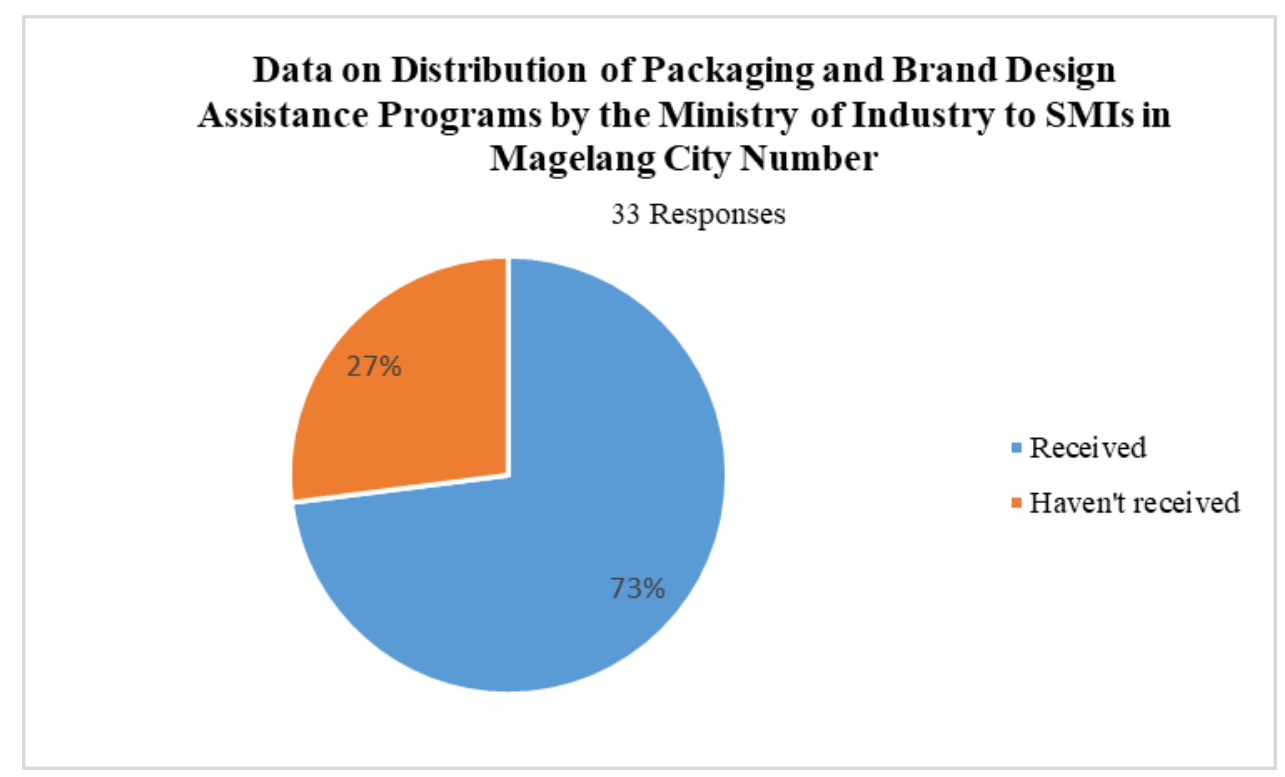

Table 2. Data on Distribution of Packaging and Brand Design Assistence Programs

Source: Archives of the City of Magelang Disperindag 2019

\section{Sustainability after Program Distribution in Achieving Its Goals}

Completion of program distribution is not the final goal for the implementation of this Packaging and Brand Design assistance program, but instead returns to the original goal of the program previously described, namely improving product quality so that SMIs are able to face global competition. So to find out the sustainability of this program, researchers conducted interviews with 33 (ten) SMIs listed above and asked questions about the development of their products before and after the distribution of the program. The questions then develop towards the problems they face and the future plans for SMIs to utilize the facilities of this assistance program.

The results of the interviews were then analyzed in a simple manner, supported by direct observations by researchers in the field, secondary data, and statements from the perspective of industry assistants in the Industry and Trade Office of Magelang City. So that descriptive conclusions can be drawn without generalizing. Given that qualitative research tends to emphasize meaning, while meaning is highly dependent on the process, research must prioritize explaining the process rather than the product. (Nugrahani, 2014). The results of the interview are stated in a diagram and then interpreted into descriptive sentences.

From the SMI players who received packaging and brand design facilities stated that the designs received were very satisfying, because the designs became more modern and attractive than before so they were expected to attract the attention of new consumers. However, the diagram above shows that of the 24 responses of respondents who have received program assistance, $88 \%$ have used the New design. Meanwhile, 13\% admitted that they still used the old design for several reasons, 
including consuming the old packaging stock that had already been printed, there were also those who admitted that they still had doubts about starting with new packaging because the old packaging was already widely known. In line with that, $88 \%$ of the SMIs who have used the new design admit that they need to make extra efforts to convince old customers that with new acidity, the product content remains the same. As for the efforts they do, one of them is by making several adjustment steps, such as incorporating elements of the previous brand design into the new brand design so that it is easily understood by old customers.

However, out of 24 responses, $67 \%$ admitted that there was a market expansion in the marketing of their products. Products that previously could only be marketed through sales to traditional markets by means of kilograms or entrusted to grocery stalls in Magelang City, now they are more confident to offer to a wider market. One of them is by starting to dare to advertise through social media and offer products through e-commerce. This is because the new packaging is more photogenic and instagramable, the products are also being attracted by resellers from outside the city. Another response said that since using the new packaging, its products can start to be marketed in supermarkets and at souvenir centers. They also said that many consumers have a good response because the product looks much more attractive to buyers' eyes when put alongside other products. On the other hand, 33\% has not or has not experienced market expansion. The disbursement that was carried out in stages made some SMIs only receive assistance at almost mid-2020 so that they had not had the opportunity to undertake a market expansion strategy.

The results of an interview conducted with an SMI actor who was lucky to receive assistance in the form of physical packaging, namely the Cheese Stick product with the RAKEDAM brand, admitted that he was very grateful for the new packaging and had started distributing it in the market. The new packaging is considered to meet the requirements for good packaging which is linked to the indicators of product quality, namely: (1) Performance, crispy snacks will remain crispy with packaging according to their needs; (2) An additional feature, the packaging has the characteristics that display the logo of RAKEDAM and an appetizing Cheese Stick image, the packaging is also accompanied by information regarding the composition and nutritional content that is beneficial to consumers; (3) Reliability, standing pouch packaging made of aluminum foil which is airtight so that the taste is maintained; (4) Compliance with specifications, namely meeting the standards required for food products, as well as the presence of product information such as product net weight which makes it possible for buyers to make comparisons; (5) Durability, standing pouch packaging with aluminum foil material is considered to make the product more durable and not easily crushed; (6) Aesthetics, sweetened with a modern design, makes the packaging more attractive and looks more exclusive.

The obstacles faced are when later the physical packaging assistance from this program has run out, they are required to continue to use packaging with the same design to maintain consumer loyalty. On the other hand, not many printing companies 
/ packaging manufacturers in Magelang can accept orders with the same design. Even if there is, the quality of the ingredients is not the same and the price is higher. If SMI wants the same quality, they can order from a printer in Semarang or Yogyakarta, of course this requires additional costs. Meanwhile, previous research by Puspaningrum (2016) shows that production costs have an effect on determining the selling price.

The statement of the SMI actors who received this benefit was also supported by the statement addressed by the industrial function and the SMI assistant from the Office of Industry and Trade of the City of Magelang. Even though the distribution of the program went well, the obstacles faced by the seriousness of the SMI actors after the assistance was distributed. Many of the SMI players are impatient and maintain the principle that with makeshift, cheap, and easy-to-get packaging their products can still be accepted in the local market. They are satisfied with it and less ambitious to develop the potential of the product.

\section{Conclusion}

The procedure for submitting the Packaging and Brand Design Assistance program to Magelang City SMI can be done independently or on the basis of a recommendation by the Magelang City Industry and Trade Office. By following the procedure and completing the requirements, the application form will be forwarded to the Packaging and Brand Design Development Clinic in Jakarta. If the application is accepted, the program will be distributed to the beneficiary SMI.

Of the 24 SMIs, $88 \%$ have used new packaging designs and $67 \%$ have experienced market expansion. Attractive new brand and packaging designs make businesses more confident about promoting and advertising digitally. Packaging designs that comply with standards also allow business actors to market their products to a wider area. On the other hand, 13\% have not used a new design and 33\% have yet to expand the market. The reason is, the perpetratorstill have doubts about starting with a new packaging because the old packaging is already widely known. Business actors also need to make extra efforts to convince old customers that with new acidity, the contents of the product remain the same.

\section{Suggestion}

For the government and related institutions that handle this program, it is recommended that if the assessment of applications can be carried out in areas that are faster and not necessarily to the center in Jakarta. This can save more money and time. Meanwhile, SMI can use a product packaging differentiation strategy for each segment. For example, old consumers who are loyal and want a product that has a populist impression and affordable prices can use the old packaging, while for market expansion to the upper middle segment can use packaging with a new design that has a hygienic and exclusive impression. 
Suggestions for further research are expected to develop this research by analyzing the achievement of program objectives from a consumer or other perspective and using a quantitative approach so that the success of the program can be measured.

\section{References}

Bogdan, Robert C. \& Biklen Kopp Sari. (1982). Qualitative research for Education: An Introductionto Theory and Methods. Alyyn and Bacon.Inc. Boston London

Cenadi, S. Suharto. (2000). Peranan Desain Kemasan dalam Dunia Pemasaran. Jurnal NIRMANA. Volume 2, Number 1, pp 92-103

Firmansyah, Anang. (2019). Pemasaran Produk dan Merek (Planning \& Strategy). Surabaya: CV. Penerbit Qiara Media

Gecti, Fatih \& Hayrettin Zengin.(2013). The Relationship between Brand Trust, Brand Affect, Attitudinal Loyality an Behavioral Loyality: A Field Study toward Sports Shoe Consumers in Turkey. International Journal of Marketing Studies. Volume 5, Number 2, pp.111-119

Kemenperin (2020). Kemenperin: Desain Kemasan Produk IKM Perlu Dukung Protokol Kesehatan. Accessed from http://kemenperin.go.id/artiel/21965/Kemenperin:-DesainKemasan_Produk-IKM-Perlu-Dukung-Protokol-Kesehatan

Kotler, Philip. \& Gary Armstrong. (2008). Prinsip-prinsip Pemasaran. Jakarta: Erlangga.

Moleong, Lexy J. (2011). Metode Penelitian Kualitatif. Bandung : Remaja Rosda Karya.

Muhadjir, Noeng. (1996). Metode Penelitian Kualitatif. Yogyakarta: Rake Sarasin

Mundir, Abdillah. (2012). Mutu Produk. http://ilmiah-jurnal.blogspot.com/2012/08/mutuproduk.html?m=1 tanggal 28 Mei 2020

Nugrahani, Farida. (2014). Metode Penelitian Kualitatif. Surakarta: Cakra Books

Puspaningrum, Yunita. (2006). Pengaruh Biaya Produksi terhadap Harga Jual Kacang Atim pada Perusahaan Gajah Semarang. Skripsi. Fakultas Ekonomi. Universitas Negeri Semarang.

Regulation of the Minister of Industry of the Republic of Indonesia Number 64 of 2016 concerning the Amount of Labor and Investment Value for Classification of Industrial Businesses

Sahban, Hernita. (2017). Menembus Badai UMKM. Makassar: CV.SAH MEDIA.

Santia, Tira. (2020). Kontribusi Ekspor Produk UMKM Masih Rendah. https://bit.ly/2Zfb8hu. Retrieved December 23, 2020.

Simamora, Bilson. (2003). Aura Merek: 7 Langkah Membangun Merek yang Kuat. Jakarta: Gramedia Pustaka.

Susilo, Y Sri. (2007). Pertumbuhan Usaha Industri Kecil dan Menengah (IKM) dan Faktorfaktor yang Mempengaruhinya. Eksekutif. Volume 4, Number 2, pp.306-313

Tjiptono, Fandy. (2015). Strategi Pemasaran. $4^{\text {th }}$ Edition. Yogyakarta: ANDI 
Wardhani, R.Susi \& Yulia Agustina. (2015). Analisis Faktor-faktor yang Memengaruhi Daya Saing pada Sentra Industri Makanan Khas Bangka di Kota Pangkalpinang. Jurnal Akuntansi Universitas Jember. Volume 10, Number 2.

Wirya, I. (1999). Kemasan yang Menjual. Jakarta: PT. Gramedia Pustaka Utama

World Bank. (2005). Supporting Small and Medium Enterprises. Policy Brief. Accessed from http://www.worldbank.or.id on December 20, 2020. 